\title{
Production of exotoxins by two luminous Vibrio harveyi strains known to be primary pathogens of Penaeus monodon larvae
}

\author{
L. J. Harris*, L. Owens \\ Department of Microbiology and Immunology, James Cook University, Townsville, Queensland 4811, Australia \\ and
}

The Cooperative Research Centre for Aquaculture, PO Box 123, Broadway, Sydney, New South Wales 2007, Australia

\begin{abstract}
Two luminous strains of Vibrio harveyi, previously demonstrated to be virulent to Penaeus monodon larvae were shown to produce proteinaceous exotoxins capable of causing mortality in mice and $P$. monodon at relatively small concentrations. These toxins were isolated from cell-free supernatants of mid-exponential phase broth cultures. Toxin T1, produced by V. harveyi strain 47666-1, had an $\mathrm{LD}_{50}$ of $2.1 \mu \mathrm{g} \mathrm{g}^{-1}$ by intra-peritoneal injection in CBA mice and $1.8 \mathrm{\mu g} \mathrm{g}^{-1}$ by intra-muscular injection in juvenile $P$. monodon. This protein comprised 2 subunits of approximately 55 and $45 \mathrm{kDa}$, giving the native protein a weight of approximately $100 \mathrm{kDa}$. Toxin T2, produced by $V$. harveyi strain 642 , had an $\mathrm{LD}_{50}$ of $3.1 \mu \mathrm{g} \mathrm{g}^{-1}$ by intra-peritoneal injection in CBA mice and $2.2 \mu \mathrm{g} \mathrm{g}^{-1}$ by intra-muscular injection in juvenile $P$. monodon. Partial sequencing of both toxins did not reveal definitive matches to other known bacterial proteins. However, some partial homology to toxin or toxin-associated proteins was found. These toxins are likely to be important virulence factors for these strains. The quantity, type and mode of action of toxins such as these, when expressed by virulent $V$. harveyi strains, may provide an explanation for the variability in virulence which has been observed for this species
\end{abstract}

KEY WORDS: Vibrio harveyi Penaeus monodon larvae - Virulence $\cdot$ Exotoxins

\section{INTRODUCTION}

Vibrio harveyi is recognised as an important pathogen of cultured penaeid larvae throughout the southeast Asian region (Lavilla-Pitogo et al. 1990, Jiravanichpaisal et al. 1994, Karunasagar et al. 1994). In the intensive culture of the black tiger prawn Penaeus monodon, virulent strains of $V$. harveyi cause devastating mortality in the hatchery stage (Sunaryanto \& Mariam 1986, Lavilla-Pitogo et al. 1990, Karunasagar et al. 1994). The disease phenomenon caused by these strains is commonly referred to as luminous bacterial disease (Lavilla-Pitogo et al. 1990) or luminous vibriosis. Diseased prawn larvae are characterised by weak-

-Address for correspondence: Seafarm Pty Ltd, Ella Bay Rd, Flying Fish Point, Innisfail, Queensland 4860, Australia.

E-mail: lachlanharris@internetnorth.com.au ness, opaque colour, feeble and intermittent swimming movements and greenish luminescence (Lavilla-Pitogo et al. 1990, Karunasagar et al. 1994).

There is great variation between Vibrio harveyi strains in terms of virulence to Penaeus monodon larvae. Highly virulent strains kill up to $100 \%$ of $P$. monodon protozoea in baths containing as little as $10^{2}$ colony forming units (CFU) $\mathrm{ml}^{-1}$ (Lavilla-Pitogo et al. 1990) whereas many other strains are avirulent at $10^{6} \mathrm{CFU} \mathrm{m} \mathrm{m}^{-1}$ (Pizzutto \& Hirst 1995). The factors involved in the pathogenicity of virulent strains of $V$. harveyi to $P$. monodon larvae have not been well characterised. Pizzutto \& Hirst (1995) found that the virulence of $V$. harveyi strains to $P$. monodon was not related to phylogeny. Owens et al. (1996) showed that there was a relationship between siderophore production and virulence for piscine infecting $V$. harveyi, but the same relationship was not seen for strains infecting inverte- 
brates. $V$ harveyi strains are known to produce chitinases (Svitil et al. 1997) and proteases (Fukasawa et al. 1988, Liu et al. 1996b) but the relationship between these factors and virulence is not clear. It seems to be a requirement of $V$. harveyi strains that cause brown gill disease in adult $P$. monodon that the bacterium must also be infected with a bacteriophage (Ruangpan et al. 1999). It is also possible that phage-encoded factors may contribute to the virulence of $V$. harveyi strains that cause larval disease.

Exotoxins have been suggested to be involved in luminous bacterial disease based on histopathology characteristic for toxicosis in infected larvae (Muir 1991) and on the toxicity of extra-cellular products of Vibrio harveyi when injected into adult Penaeus monodon (Liu et al. 1996a). However, the identity and the role of the putative toxins involved in the virulence of $V$. harveyi strains has not yet been elucidated. In addition to the well characterised toxins produced by Vibrio cholerae (Sears \& Kaper 1996) and Vibrio parahaemolyticus (Honda et al. 1992), many environmental Vibrio spp. produce extracellular toxic factors (Venkateswaran et al. 1991). Exotoxin production by Vibrio spp. has been shown to be involved in disease outbreaks in other cultured invertebrate larvae. Examples include a Vibrio anguillarum strain that causes disease in cultured Crassostrea gigas (Japanese oyster) (DiSalvo et al. 1978) and a Vibrio species that causes epizootics in Crassostrea virginica (American oyster) (Brown \& Roland 1984). Widely distributed marine toxins such as tetrodotoxin and the surugatoxins are known to have a bacterial origin (Yasumoto \& Murata 1993), and both tetrodotoxin and anhydrotetrodotoxin have been shown to be produced by $V$. harveyi strains isolated from seawater (Simidu et al. 1987). Alkaline proteases have been extracted from broth culture supernatant of 2 luminous strains of $V$. harveyi, originally isolated from seawater (Fukasawa et al. 1988, 1989). Similarly, a cysteine protease was extracted from the broth culture supernatant of a $V$. harveyi strain isolated from diseased adult P. monodon (Liu et al. 1996b). However, the toxic activity or further study of any action of this protease in $P$. monodon has not yet been reported.

This study investigated cell-free culture supernatants of Vibrio harveyi strains isolated from a variety of sources for the presence of toxic factors. Many of these strains, including 2 strains known to be virulent to Penaeus monodon larvae, were also used in the studies of Muir (1991) and Pizzutto \& Hirst (1995). Our intention was to determine whether the production of exotoxins played a crucial role in the disease pathogenesis caused by $V$. harveyi in $P$. monodon larvae and whether the type and mode of action of the putative toxin or toxins could provide an explanation for the variability in virulence of $V$. harveyi strains.

\section{MATERIALS AND METHODS}

Source of bacterial strains. Ten Vibrio harveyi strains from a variety of sources were used in this study. The original source for 8 of these strains was given previously by Pizzutto \& Hirst (1995). In addition strain $M 1$ was isolated from a septicaemic adult Penaeus monodon and strain 46802-1 was isolated from moribund Scylla serrata (mud crab) larvae (M. Pizzutto pers. comm. 1996). The virulence of strains 47666-1 (Muir 1991, Pizzutto \& Hirst 1995) and ACMM (Australian Collection of Marine Microorganisms) 642 (Pizzutto \& Hirst 1995) to P. monodon larvae has been shown previously.

Storage and incubation conditions of bacterial strains. Bacterial strains were preserved in liquid nitrogen. Before use in subsequent experiments, they were resuscitated onto luminous agar (Reichelt \& Baumann 1973) and checked for purity. Cultures grown on agar were incubated at $28^{\circ} \mathrm{C}$. Broth cultures were maintained at $28^{\circ} \mathrm{C}$ and shaken at $200 \mathrm{rpm}$ in an orbital shaker incubator (Paton Industries Ltd, Stepney, Australia).

Preparation of cell-free supernatants. Sterile luminous broth (Reichelt \& Baumann 1973) was inoculated with a loopful of a Vibrio harveyi strain from an overnight culture. This culture was grown to a density which gave an absorbance value of $0.4 \pm 0.01$ at $600 \mathrm{~nm}$, after dilution of 1 in 10 in phosphate buffered saline (PBS). This corresponded to a cell density of approximately $5 \times 10^{9} \mathrm{CFU} \mathrm{ml}^{-1}$. Two $\mathrm{ml}$ disposable cuvettes (Sarstedt, Adelaide, Australia) were used to measure absorbance in an Ultrospec III spectrophotometer (Amrad Pharmacia Biotech, Boronia, Australia). Cells were pelleted by centrifugation at $10000 \mathrm{rpm}$ $(12200 \times g)$ for $20 \mathrm{~min}$. The supernatant was harvested and filtered through a $0.22 \mu \mathrm{m}$ disposable syringe filter (Sartorius, Melbourne, Australia).

Concentration of the supernatant. A 50 to 100 times concentration of the supernatant was achieved by membrane filtration. Two sorts of membranes and filter devices were used:

(1) For the preparation of samples for gel filtration chromatography, approximately 1 l of supernatant was concentrated by filtration through a $62 \mathrm{~mm}$ YM10 (10 kDa) Diaflo ultrafiltration membrane (Australasian Medical and Scientific, Brisbane, Australia) in an Amicon (Millipore, Sydney, Australia) model 8200 ultrafiltration stir-cell at $4^{\circ} \mathrm{C}$, under pressure of nitrogen gas applied at $350 \mathrm{kPa}$. For this purpose $1 \mathrm{l}$ of supernatant was typically concentrated to $10-20 \mathrm{ml}$ of sample. This preparation of concentrated supernatant was termed the cell-free supernatant extract (CFSE). Preparation of CFSE by this method took approximately $4 \mathrm{~h}$. 
(2) For the preparation of smaller volumes of CFSE, the supernatant was spun, at $4^{\circ} \mathrm{C}$, through an Ultrafree 15 centrifugal filter (Millipore, Sydney, Australia) at $3000 \mathrm{rpm}(1100 \times \mathrm{g})$ using a swinging bucket rotor in a Clements 2000 benchtop centrifuge (Clements, Sydney, Australia). Typically $15 \mathrm{ml}$ of supernatant was concentrated to approximately $150 \mu \mathrm{l}$ in $60 \mathrm{~min}$ at this speed. The CFSE from several centrifugal filters was pooled to ensure that adequate quantities of these preparations were available for experiments.

Purification of protein fractions from CFSE. The CFSE of Vibrio harveyi strain 47666-1 was fractionated using a S-100 26/60 Hi-Prep Sephacryl gel filtration column (Amrad Pharmacia Biotech, Boronia, Australia). A Bio-Rad (North Ryde, Australia) Econo-pump set at a flow rate of $0.5 \mathrm{ml} \mathrm{min}^{-1}$ was used to run the samples and protein buffer $(50 \mathrm{mM} \mathrm{NaPO}, 0.15 \mathrm{M} \mathrm{NaCl}, 0.22 \%$ $\mathrm{NaN}_{3}$ ) through the column. After an initial void volume of $80 \mathrm{ml}$ was allowed to pass through the column, 50 fractions of $6 \mathrm{ml}$ were collected using a model 2218 fraction collector (Bio-Rad, North Ryde, Australia). The absorbance of these fractions was measured at $254 \mathrm{~nm}$ and the eluted fractions showing absorbance peaks were selected for further analysis. $V$. harveyi strain ACMM 642 concentrated CFSE was fractionated in the same manner but using a S-200 26/60 Hi-Prep Sephacryl gel filtration column. It was necessary to process 3 samples of $10 \mathrm{ml}$ of CFSE per strain through the columns in order to extract enough protein for toxicity trials.

Concentration of protein fractions. Protein fractions eluted by gel filtration chromatography were concentrated for further analysis by centrifugation through Centricon-10 centrifugal filters as detailed in the Amicon (Millipore, North Ryde, Australia) instruction manual (Publication I-259Q). These fractions were concentrated by a factor of 10 for toxicity trials using CBA mice or Penaeus monodon or for PAGE.

Protein estimation. Estimation of total protein in solution was performed by the Pierce BCA method (Progen Industries, Darra, Australia).

Challenge of Penaeus monodon larvae. Bath challenge of $P$. monodon protozoea was perfomed by the method used by Muir (1991) and Pizzutto \& Hirst (1995). Protozoea were challenged with 10-fold increments of doses of CFSE starting from $1 \mu \mathrm{l}$ up to $1 \mathrm{ml}$ of CFSE per flask of 15 larvae in $150 \mathrm{ml}$ of seawater. An equivalent volume of luminous broth was used as a broth control. The larvae were also challenged with $10^{6}$ and $10^{4} \mathrm{CFU} \mathrm{ml} \mathrm{m}^{-1}$ of strains $47666-1$ and ACMM 642. Cells were washed 3 times in sterile artificial seawater (ASW) (Reichelt \& Baumann 1973) before being used for bath inoculation. Survival was assessed after 40 h from initial challenge.

Inoculation of juvenile Penaeus monodon and CBA mice. Juvenile prawns were inoculated, with CFSE or concentrated protein fractions, by intra-muscular injection into the third abdominal segment anterior to the telson. A dose volume of $50 \mu \mathrm{l}$ was used. Groups of 5 or more prawns with less than $2 \mathrm{~g}$ variation in weight were used per dose. Smaller prawns (2 to $5 \mathrm{~g}$ ) were used for injection with protein fractions to minimise the amount of protein required. Larger prawns (6 to $12 \mathrm{~g}$ ) were used for injection with CFSE. CBA mice (15 to $25 \mathrm{~g})$ were inoculated, with CFSE or concentrated protein fractions, by intra-peritoneal injection. A dose volume of $100 \mu \mathrm{l}$ was used. Groups of 3 mice with less than $1 \mathrm{~g}$ variation in weight were used per dose. The number of mice used was minimised for ethical considerations.

Challenge of animals with CFSE. Juvenile Penaeus monodon and CBA mice were challenged with CFSE from 10 Vibrio harveyi strains. In initial experiments, the CFSE solutions were adjusted, based on an approximate mean weight of $20 \mathrm{~g}$ for the mice and $9 \mathrm{~g}$ for the prawns, to give a dosage per treatment group of approximately either 10 or $50 \mathrm{\mu g} \mathrm{g}^{-1}$. However, due to variation in the weight of the animals, these doses varied slightly between treatment groups. By $96 \mathrm{~h}$ after injection the animals had either died from the effects of toxin or seemed to have fully recovered. The survival of animals was recorded every $12 \mathrm{~h}$ after injection and these observations, as well as survival at $96 \mathrm{~h}$, were used in survival analysis to distinguish differences between treatment groups by pairwise comparison. Prawns which died in less than an hour following inoculation were discounted from the experiments as it was considered more likely that these animals were dying from protein shock rather than from toxic effects. Subsequent experiments with lower doses of the CFSE derived from $V$. harveyi strains 47666-1 and ACMM 642 were performed under these same experimental parameters

Challenge of animals with protein fractions. In initial experiments to determine the activity of protein fractions, the inocula for CBA mice were adjusted, by dilution with protein buffer if necessary, to deliver a dose of approximately $5 \mu \mathrm{g} \mathrm{g}^{-1}$. In subsequent experiments with targeted protein fractions, other doses were used for challenge of mice and Penaeus monodon. Experimental parameters for inoculation and observations of survival for these experiments were the same as previously explained.

Challenge with control inocula. A control group of juvenile Penaeus monodon and CBA mice per experiment were injected with PBS as a diluent control. Another group was inoculated with bovine serum albumin (BSA) (Sigma, St. Louis, USA) suspended in PBS to administer a dose equivalent to the highest protein dose being administered in the form of CFSE or concentrated protein fractions (CPF) per experiment. This served as an inert protein control. 
Calculation of specific activity units (U). The lowest dose of CFSE or protein fractions, for strains 47666-1 and ACMM 642, which caused significant mortality in Penaeus monodon compared to animals injected with control inocula of PBS or BSA was designated to comprise $1 \mathrm{U}$ of toxic activity. As the total amount of protein injected in this dose was known, U per mg of protein in the preparation could then be calculated. Thus, the specific activity of preparations of CFSE and of protein fractions was calibrated in terms of these units of prawn toxicity.

Poly-acrylamide gel electrophoresis (PAGE) analysis. One-dimensional poly-acrylamide gels of $7.5 \mathrm{~cm}$ length, using $0.25 \mathrm{~mm}$ spacers, with a $10 \%$ separating gel were prepared and run by the method of Laemmli (1970) at $200 \mathrm{~V}$ in a Mini-Protean II electrophoresis cell. Both denaturing and native PAGE gels were used. The preparation and running conditions for both types of gels were identical except that for native gels the samples were not boiled, and sodium dodecyl sulphate (SDS) and 2-mercaptoethanol were excluded from both the loading and running buffers. Broad range molecular weight standards (Bio-Rad, North Ryde, Australia) were used as markers for denaturing gels. Protein bands were visualised by staining with either Coomassie blue or silver.

Statistical analysis. $L_{50}$ values were calculated by probit analysis (logistic regression analysis) of dose response models. To differentiate statistically significant treatment groups, survival analysis with pairwise comparisons of treatment groups according to dose and time was used to analyse data for survival of CBA mice and juvenile Penaeus monodon whereas 1-way ANOVA was used to analyse survival data for prawn larvae. SPSS for Windows (SPSS Inc., Chicago, USA) was used to perform all these types of analysis.

Protein sequencing and analysis. Toxic protein fractions extracted from CFSE by gel filtration chromatography were sent to Auspep Pty Ltd (Parkville, Australia) for analysis. The respective toxic proteins for strains ACMM 642 and 47666-1 were estimated to comprise greater than $90 \%$ of the total protein in solution in these fractions. This estimation was based on the relative intensities of protein bands seen in these fractions when visualised by either silver or Coomassie staining compared to the total protein known to be in solution in the protein buffer. A $10 \mu l$ aliquot of the protein solution was loaded onto the ABI Procise ${ }^{T M}$ protein sequencer (PE Applied Biosystems Inc., Foster City, USA). The sequencer was set for 1 blank and 1 standard run and 8, 9 or 10 analytical cycles. Proteins which were found to be blocked at the N-terminal were then digested by trypsin. Fractions of the digests were isolated by high pressure liquid chromatography (HPLC) and then prepared for analytical cycles as previously explained. The amino acid sequences obtained were checked for homology against the Australian National Genomic Information Service (ANGIS) database.

\section{RESULTS}

\section{Toxicity of CFSE from Vibrio harveyi strains}

The survival of animals from each treatment group after $96 \mathrm{~h}$ following inoculation is shown (Table 1). PBS challenges did not affect either mice or prawns adversely. Challenges of $50 \mu \mathrm{g} \mathrm{g}^{-1}$ of BSA resulted in a decrease in activity and alertness of mice for approximately $2 \mathrm{~h}$ following injection but all mice recovered fully from this challenge. Similarly for prawns which

Table 1. Survival of CBA mice and juvenile Penaeus monodon after injection with cell-free supernatant extract (CFSE) extracted from broth cultures of Vibrio harveyi strains. Significant differences in survival compared to control animals injected with PBS and BSA are indicated by the groups marked with letters a to $g$. Numbers in parentheses indicate the number of injected mice and the number of injected $P$. monodon which survived the

$1 \mathrm{~h}$ period necessary for discounting the effects of protein shock

\begin{tabular}{|c|c|c|c|c|}
\hline $\begin{array}{l}V . \text { harveyi } \\
\text { strain } \\
\text { number }\end{array}$ & $\begin{array}{l}\text { Dose }\left(\mu g g^{-1}\right) \\
\quad \text { for CBA } \\
\quad \text { mice }\end{array}$ & $\begin{array}{l}\text { Survival of } \\
\text { mice after } \\
\quad 96 \mathrm{~h}\end{array}$ & $\begin{array}{l}\text { Dose }\left(\mu g^{-1}\right) \\
\quad \text { for } \\
\text { P. monodon }\end{array}$ & $\begin{array}{l}\text { Survival of } \\
\text { P. monodon } \\
\text { after } 96 \mathrm{~h}\end{array}$ \\
\hline 1 & $\begin{array}{l}48.2 \\
10.6\end{array}$ & $\begin{array}{l}3(3) \\
3(3)\end{array}$ & $\begin{array}{l}51.2 \\
9.5\end{array}$ & $\begin{array}{l}5(6) \\
5(5)\end{array}$ \\
\hline 8 & $\begin{array}{l}46.7 \\
10.2\end{array}$ & $\begin{array}{l}3(3) \\
3(3)\end{array}$ & $\begin{array}{l}50.3 \\
10.9\end{array}$ & $\begin{array}{l}5(5) \\
4(5)\end{array}$ \\
\hline 656 & $\begin{array}{l}49.0 \\
10.6\end{array}$ & $\begin{array}{l}3(3) \\
3(3)\end{array}$ & $\begin{array}{l}51.4 \\
12.3\end{array}$ & $\begin{array}{l}3(6) \\
5(5)\end{array}$ \\
\hline 9056681 & $\begin{array}{c}48.5 \\
9.9\end{array}$ & $\begin{array}{l}3(3) \\
3(3)\end{array}$ & $\begin{array}{l}50.7 \\
10.3\end{array}$ & $\begin{array}{l}5(5) \\
5(5)\end{array}$ \\
\hline 52 & $\begin{array}{l}50.1 \\
11.7\end{array}$ & $\begin{array}{l}3(3) \\
3(3)\end{array}$ & $\begin{array}{l}48.9 \\
10.4\end{array}$ & $\begin{array}{l}4(6) \\
4(5)\end{array}$ \\
\hline M1 & $\begin{array}{l}49.8 \\
10.5\end{array}$ & $\begin{array}{l}3(3) \\
3(3)\end{array}$ & $\begin{array}{l}49.0^{a} \\
11.3\end{array}$ & $\begin{array}{l}3(7) \\
5(5)\end{array}$ \\
\hline PM 91 & $\begin{array}{l}51.5 \\
12.0\end{array}$ & $\begin{array}{l}1(3) \\
3(3)\end{array}$ & $\begin{array}{l}50.6^{\mathrm{b}} \\
11.5\end{array}$ & $\begin{array}{l}2(6) \\
4(5)\end{array}$ \\
\hline $46802-1$ & $\begin{array}{l}47.1 \\
10.5\end{array}$ & $\begin{array}{l}3(3) \\
3(3)\end{array}$ & $\begin{array}{l}49.5^{c} \\
10.3\end{array}$ & $\begin{array}{l}1(5) \\
5(5)\end{array}$ \\
\hline $47666-1$ & $\begin{array}{l}50.6^{\mathrm{d}} \\
11.2^{\mathrm{d}}\end{array}$ & $\begin{array}{l}0(3) \\
0(3)\end{array}$ & $\begin{array}{l}50.4^{\mathrm{e}} \\
11.9^{1}\end{array}$ & $\begin{array}{l}0(7) \\
0(6)\end{array}$ \\
\hline 642 & $\begin{array}{l}52.0^{\mathrm{d}} \\
10.4^{\mathrm{d}}\end{array}$ & $\begin{array}{l}0(3) \\
0(3)\end{array}$ & $\begin{array}{l}51.8^{e} \\
10.6^{\mathrm{g}}\end{array}$ & $\begin{array}{l}0(7) \\
2(7)\end{array}$ \\
\hline \multicolumn{5}{|c|}{$\begin{array}{l}{ }^{\mathrm{d}}(G=3.929, \mathrm{df}=1, \mathrm{p}=0.0475),{ }^{\mathrm{b}}(G=4.762, \mathrm{df}=1, \mathrm{p}=0.0291) \\
{ }^{\mathrm{c}}(G=6.000, \mathrm{df}=1, \mathrm{p}=0.0143),{ }^{\mathrm{d}}(G=5.000, \mathrm{df}=1, \mathrm{p}=0.0253) \\
(G=11.000, \mathrm{df}=1, \mathrm{p}=0.0009),{ }^{\mathrm{f}}(G=10.000, \mathrm{df}=1, \mathrm{p}=0.0016) \\
(G=5.612, \mathrm{df}=1, \mathrm{p}=0.0178)\end{array}$} \\
\hline
\end{tabular}


survived the initial period for discounting protein shock, a decrease in activity and cessation of feeding and swimming for a period of up to $12 \mathrm{~h}$ was noticed, but no further mortalities resulted from this treatment. In comparison to the PBS and BSA control groups, for an approximate dose of $50 \mu \mathrm{g}$ $\mathrm{g}^{-1}$, the CFSE from 2 strains of Vibrio harveyi resulted in significantly lower survival for CBA mice. These were strains ACMM 642 and 47666-1. The CFSE from strain PM 91 did result in the death of 2 mice at this dose, but due to the fact that only 3 mice were injected per dose in this experiment, this survival was not significantly different to control survival. Challenge of Penaeus monodon at this dose resulted in significantly lower survival compared to the controls for CFSE from strains ACMM 642, 47666-1, PM 91, M1 and 46802-1. At an approximate dose of $10 \mu \mathrm{g} \mathrm{g}^{-1}$, for both prawns and mice, significantly lower survival compared to the controls resulted only from injection with CFSE derived from strains ACMM 642 and 47666-1. Based on the results of these initial experiments, the CFSE of these 2 strains appeared to be far more toxic than that of other strains of $V$. harveyi.

\section{Toxicity of CFSE from Vibrio harveyi strains 47666-1 and ACMM 642}

Further toxicity studies were performed using the CFSE from these 2 Vibrio harveyi strains in Penaeus monodon and CBA mice. The lowest dose of CFSE for each strain which still resulted in significantly lower survival for $P$. monodon compared to control animals was designated an arbitrary specific activity value of $1 \mathrm{U}$. Determining this value enabled further comparisons of toxic activity to be made in later purification steps.

For injected PBS as a control for these studies, $8 / 8$ Penaeus monodon and $3 / 3$ CBA mice survived to $96 \mathrm{~h}$ after injection. For $8 \mu \mathrm{g} \mathrm{g}^{-1}$ injected BSA, 8/9 P. monodon and 3/3 CBA mice survived to $96 \mathrm{~h}$ after injection. The survival of animals challenged with CFSE was compared to the BSA control survivals (Table 2).

The CFSE of strain ACMM 642 caused no significant decrease in survival compared to control survival at $1.8 \mathrm{\mu g} \mathrm{g}^{-1}$ for Penaeus monodon $(G=0.963, \mathrm{df}=1, \mathrm{p}=$ 0.3263 ) and $2.4 \mu \mathrm{g} \mathrm{g}^{-1}$ for CBA mice $(G=1.000, \mathrm{df}=1$, $p=0.3173$ ). The CFSE of strain 47666- 1 caused no significant decrease in survival compared to controls at $1.5 \mathrm{\mu g} \mathrm{g}^{-1}$ for $P$. monodon $(G=1.931, \mathrm{df}=1, \mathrm{p}=0.1646$ ) and $1.9 \mu \mathrm{g} \mathrm{g}^{-1}$ for CBA mice (survival data identical). For all higher dosages of these CFSE, there were significant decreases in survival for the injected animals compared to control animals. The dosages of $2.6 \mu \mathrm{g} \mathrm{g}^{-1}$ for CFSE from strain ACMM 642 and $2.3 \mu \mathrm{g} \mathrm{g}^{-1}$ for
Table 2. Survival of CBA mice (3 per group) and Penaeus monodon (12 per group) $96 \mathrm{~h}$ following challenge with CFSE derived from broth cultures of Vibrio harveyi strains ACMM 642 and 47666-1. Significant mortality when compared to the control animals is indicated by the letters a to $\mathrm{f}$, which refer to specific statistical data given below the table. Numbers in parentheses indicate the numbers of injected control animals which survived the $1 \mathrm{~h}$ period necessary for discounting the effects of protein shock

\begin{tabular}{|c|c|c|c|c|}
\hline $\begin{array}{l}\text { Source of CFSE } \\
\text { used for inoculum }\end{array}$ & $\begin{array}{c}\text { Dose } \\
\left(\mu g^{-1}\right)\end{array}$ & $\begin{array}{l}\text { Survival of } \\
P . \text { monodon }\end{array}$ & $\begin{array}{c}\text { Dose } \\
\left(\mu \mathrm{g} \mathrm{g}^{-1}\right)\end{array}$ & $\begin{array}{l}\text { Survival of } \\
\text { CBA mice }\end{array}$ \\
\hline ACMM 642 & $\begin{array}{l}5.2^{\mathrm{a}} \\
3.4^{\mathrm{c}} \\
2.6^{\mathrm{d}} \\
1.8\end{array}$ & $\begin{array}{l}4(11) \\
4(10) \\
5(12) \\
7(10)\end{array}$ & $\begin{array}{l}6.6^{b} \\
4.6 \\
2.4\end{array}$ & $\begin{array}{l}0(3) \\
1(3) \\
2(3)\end{array}$ \\
\hline $47666-1$ & $\begin{array}{l}7.4^{\mathrm{e}} \\
3.6^{\mathrm{a}} \\
2.3^{\mathrm{i}} \\
1.5\end{array}$ & $\begin{array}{l}1(7) \\
4(11) \\
5(11) \\
6(10)\end{array}$ & $\begin{array}{l}7.5^{\mathrm{b}} \\
3.6 \\
1.9\end{array}$ & $\begin{array}{l}0(3) \\
1(3) \\
3(3)\end{array}$ \\
\hline \multicolumn{5}{|c|}{$\begin{array}{l}{ }^{\mathrm{d}}(G=5.406, \mathrm{df}=1, \mathrm{p}=0.0201),{ }^{\mathrm{b}}(G=5.000, \mathrm{df}=1, \mathrm{p}=0.0253), \\
{ }^{\mathrm{c}}(G=4.610, \mathrm{df}=1, \mathrm{p}=0.0318),{ }^{\mathrm{d}}(G=4.631, \mathrm{df}=1, \mathrm{p}=0.0314), \\
{ }^{\mathrm{d}}(G=8.348, \mathrm{df}=1, \mathrm{p}=0.0039),{ }^{\prime}(G=3.900, \mathrm{df}=1, \mathrm{p}=0.0483)\end{array}$} \\
\hline
\end{tabular}

CFSE from strain 47666 - 1 were designated to comprise $1 \mathrm{U}$ of toxic activity.

\section{Purification of protein fractions from CFSE by gel filtration chromatography}

Protein fractions from strains 47666-1 and ACMM 642 were obtained by elution from the S-100 and S-200 columns, respectively. Following a void volume of $80 \mathrm{ml}$, the toxic fractions for strain 47666-1 were 16, 17 and 18. These were designated concentrated protein fractions (CPF) 16,17 and 18. The toxic fractions for strain ACMM 642 were CPF 2, 3 and 4 (Table 3). For both strains, other fractions showing protein peaks did not affect the mice adversely within $96 \mathrm{~h}$ (Table 3 ).

\section{Further study of the toxicity of CPF $17(47666-1)$ and CPF 3 (ACMM 642)}

CBA mice and Penaeus monodon were challenged with dilutions of these protein fractions in order to determine an $\mathrm{LD}_{50}$ and a minimum toxic dose. The lowest dose which still produced a significant difference compared to survival of control animals was used for calculation of specific activity units.

All 3 mice injected with PBS survived to $96 \mathrm{~h}$ postinjection as did 3 mice injected with $5 \mu \mathrm{g} \mathrm{g}^{-1}$ of BSA. Seven of 8 Penaeus monodon injected with PBS survived until $96 \mathrm{~h}$ post-injection. Seven of $9 \mathrm{P}$. monodon injected with $5.3 \mu \mathrm{g} \mathrm{g}^{-1}$ of BSA also survived until $96 \mathrm{~h}$ post-injection. 
Table 3. Survival of CBA mice challenged with protein fractions prepared by gel diffusion chromatography from CFSE of Vibrio harveyi strains 47666-1 and ACMM 642

\begin{tabular}{|lccc|}
\hline $\begin{array}{l}V . \text { harveyi } \\
\text { strain }\end{array}$ & $\begin{array}{c}\text { Fraction } \\
\text { number }\end{array}$ & $\begin{array}{c}\text { Dose } \\
\left(\mu \mathrm{g} \mathrm{g}^{-1}\right)\end{array}$ & $\begin{array}{c}\text { Survival of } 3 \text { CBA mice } \\
96 \mathrm{~h} \text { after injection }\end{array}$ \\
\hline $47666-1$ & 1 & 5.2 & 3 \\
& 16 & 4.9 & 1 \\
& 17 & 5.2 & 0 \\
& 18 & 4.8 & 1 \\
& 24 & 5.4 & 3 \\
& 32 & 5.5 & 3 \\
ACMM 642 & 37 & 5.8 & 3 \\
& 1 & 4.6 & 2 \\
& 2 & 4.6 & 0 \\
& 3 & 5.2 & 3 \\
4 & 5.3 & 3 \\
& 32 & 4.9 & 3 \\
& 35 & 4.8 & 3 \\
& 42 & 5.5 & \\
\hline
\end{tabular}

Survival of toxin injected Penaeus monodon was not significantly different from control animals at doses of $1.3 \mathrm{\mu g} \mathrm{g}^{-1}$ for CPF $3(G=2.743, \mathrm{df}=1, \mathrm{p}=0.0977)$ and $1.1 \mu \mathrm{g} \mathrm{g}^{-1}$ for CPF $17(G=3.529, \mathrm{df}=1, \mathrm{p}=0.0603)$. Doses of $2.4 \mu \mathrm{g} \mathrm{g}^{-1}$ for CPF 3 and $2.0 \mu \mathrm{g} \mathrm{g}^{-1}$ for CPF 17 produced significant mortality compared to control animals (Table 4). These doses were assigned specific activity values of $1 \mathrm{U}$.

\section{Specific activity of CFSE and CPF}

The activity of CFSE and CPF derived from strains 47666-1 and ACMM 642 was quantified in terms of units of toxicity per $\mathrm{mg}$ of protein (Table 5). The specific activity of CFSE extracted from bacterial broth by stir-cell filtration was also calculated (survival data not shown) for comparison with CFSE extracted by the use of Ultrafree 15 centrifugal filters
Table 4. Survival of CBA mice ( 3 per group) and Penaeus monodon (12 per group) $96 \mathrm{~h}$ following challenge with CPF extracted from the CFSE of Vibrio harveyi strains ACMM 642 and 47666-1. Significant mortality when compared to the control animals is indicated by the letters a to e, which refer to specific statistical data given below the table. Numbers in parentheses indicate the numbers of injected control animals which survived the $1 \mathrm{~h}$ period necessary for discounting the effects of protein shock

\begin{tabular}{|c|c|c|c|c|}
\hline Inoculum & $\begin{array}{c}\text { Dose } \\
\left(\mu g g^{-1}\right)\end{array}$ & $\begin{array}{l}\text { Survival of } \\
\text { CBA mice }\end{array}$ & $\begin{array}{c}\text { Dose } \\
\left(\mu g g^{-1}\right)\end{array}$ & $\begin{array}{l}\text { Survival of } \\
P . \text { monodon }\end{array}$ \\
\hline $\begin{array}{l}\text { ACMM } 642 \\
\text { CPF } 3\end{array}$ & $\begin{array}{l}5.0^{a} \\
2.6 \\
1.6\end{array}$ & $\begin{array}{l}0(3) \\
1(3) \\
3(3)\end{array}$ & $\begin{array}{l}4.5^{b} \\
2.4^{c} \\
1.3\end{array}$ & $\begin{array}{l}5(10) \\
6(11) \\
8(11)\end{array}$ \\
\hline $\begin{array}{l}47666-1 \\
\text { CPF } 17\end{array}$ & $\begin{array}{l}4.3^{d} \\
2.1 \\
1.2\end{array}$ & $\begin{array}{ll}0 & (3) \\
1 & (3) \\
2 & (3)\end{array}$ & $\begin{array}{l}4.1^{\mathrm{d}} \\
2.0^{\mathrm{e}} \\
1.1\end{array}$ & $\begin{array}{l}3(10) \\
4(9) \\
8(12)\end{array}$ \\
\hline \multicolumn{5}{|c|}{$\begin{array}{l}{ }^{\mathrm{d}}(G=5.000, \mathrm{df}=1, \mathrm{p}=0.0253),{ }^{\mathrm{b}}(G=5.786, \mathrm{df}=1, \mathrm{p}= \\
0.0162),{ }^{\mathrm{c}}(G=5.182, \mathrm{df}=1, \mathrm{p}=0.0228),{ }^{\mathrm{d}}(G=9.450, \mathrm{df}=1, \\
\mathrm{p}=0.0021),{ }^{\mathrm{c}}(G=6.538, \mathrm{df}=1, \mathrm{p}=0.0106)\end{array}$} \\
\hline
\end{tabular}

$\mathrm{LD}_{50}$ of $2.1 \mu \mathrm{g} \mathrm{g}^{-1}$ by intra-peritoneal injection in CBA mice, and $1.8 \mu \mathrm{g} \mathrm{g}^{-1}$ by intra-muscular injection in $P$. monodon. CPF 3, comprising approximately equal proportions of toxin $\mathrm{T} 2$ and the non-toxic protein $\mathrm{X}$ (see Fig. 3), had an $\mathrm{LD}_{50}$ of $3.1 \mu \mathrm{g} \mathrm{g}^{-1}$ by intra-peritoneal injection in CBA mice, and $2.2 \mu \mathrm{g} \mathrm{g}^{-1}$ by intra-muscular injection in $P$. monodon.

\section{Challenge of Penaeus monodon larvae with strains 47666-1 and ACMM 642 and with CFSE derived from them}

Mean survival of larvae for all treatments from 3 replicates of 15 larvae per flask was recorded (Fig. 1) Total protein in the CFSE preparations used was estimated to be $3.6 \mathrm{mg} \mathrm{ml}^{-1}$ for both Vibrio harveyi strains. The specific activity of these preparations was there-

\section{$\mathrm{LD}_{50}$ values for CFSE and the CPF for strains 47666-1 and ACMM 642}

The $L_{50}$ values for the purified forms of the toxins derived from these Vibrio harveyl strains were lower than for CFSE (Table 6) This was expected as the total protein for CFSE included other non-toxic proteins. The $\mathrm{LD}_{50}$ values for CFSE and CPF for both strains were lower in Penaeus monodon than in mice (Table 6). CPF 17, comprising mostly toxin T1 (see Fig. 3), had an
Table 5. Calculation of the toxic activity of CFSE and CPF preparations derived from broth cultures of Vibrio harveyi strains ACMM 642 and 47666-1 Dosages shown are the minimum dose at which a significant difference between challenged Penaeus monodon and control animals was detected

\begin{tabular}{|lccc|}
\hline Type of preparation & $\begin{array}{c}\text { Minimum } \\
\text { dose }\left(\mathrm{\mu g} \mathrm{g}^{-1}\right)\end{array}$ & $\begin{array}{c}\text { Mean } \\
\text { weight of } \\
\text { P. monodon }(\mathrm{g})\end{array}$ & $\begin{array}{c}\text { Specific activity } \\
\text { of preparation } \\
\left(\mathrm{U} \mathrm{mg}^{-1}\right)\end{array}$ \\
\hline 47666-1 CFSE by stir-cell & 3.2 & 8.7 & 35.9 \\
ACMM 642 CFSE by stir-cell & 3.4 & 6.8 & 43.2 \\
47666-1 CFSE by Ultrafree 15 & 2.3 & 8.3 & 52.4 \\
ACMM 642 CFSE by Ultrafree 15 & 2.6 & 7.2 & 53.4 \\
47666-1 CPF 17 & 2.0 & 4.7 & 106.4 \\
ACMM 642 CPF 3 & 2.4 & 4.1 & 101.6 \\
\hline
\end{tabular}


Table 6. LD 50 values for CFSE of Vibrio harveyi strains 47666-1 and ACMM 642 and their respective concentrated protein fractions (CPF 17 containing toxin T1 and CPF 3 containing toxin T2) when injected into CBA mice and Penaeus monodon. $\mathrm{p}>0.05$ was considered necessary for probit analysis to be valid

\begin{tabular}{|c|c|c|c|}
\hline V. harveyi strain & Inoculum & $\mathrm{LD}_{50}$ in $\mathrm{CBA}$ mice & $\mathrm{LD}_{50}$ in $P$ monodon \\
\hline \multirow[t]{2}{*}{$47666-1$} & CFSE & $\begin{array}{l}3.9 \mu g g^{-1}\left(0.20 \mathrm{U} \mathrm{g}^{-1}\right) \\
\left(\chi^{2}=1.251, \mathrm{df}=4, \mathrm{p}=0.870\right)\end{array}$ & $\begin{array}{l}3.5 \mu g g^{-1},\left(0.18 \mathrm{U} \mathrm{g}^{-1}\right) \\
\left(\chi^{2}=11.543, \mathrm{df}=3, \mathrm{p}=0.090\right)\end{array}$ \\
\hline & CPF 17 & $\begin{array}{l}2.1 \mu g g^{-1},\left(0.22 \mathrm{U} \mathrm{g}^{-1}\right) \\
\left(x^{2}=0.000, \mathrm{df}=1, \mathrm{p}=0.985\right)\end{array}$ & $\begin{array}{l}1.8 \mu g^{-1},\left(0.19 \mathrm{U} \mathrm{g}^{-1}\right) \\
\left(\chi^{2}=1.275, \mathrm{df}=3, \mathrm{p}=0.078\right)\end{array}$ \\
\hline \multirow[t]{2}{*}{ ACMM 642} & CFSE & $\begin{array}{l}3.5 \mu g g^{-1},\left(0.19 \mathrm{U} \mathrm{g}^{-1}\right) \\
\left(\chi^{2}=0.230, \mathrm{df}=2, \mathrm{p}=0.891\right)\end{array}$ & $\begin{array}{l}3.3 \mu g g^{-1},\left(0.18 \mathrm{U} \mathrm{g}^{-1}\right) \\
\left(\chi^{2}=1.349, d f=4, p=0.853\right)\end{array}$ \\
\hline & CPF 3 & $\begin{array}{l}3.1 \mu g g^{-1},\left(0.31 \mathrm{U} \mathrm{g}^{-1}\right) \\
\left(\chi^{2}=0.003, \mathrm{df}=2, \mathrm{p}=0.998\right)\end{array}$ & $\begin{array}{l}2.2 \mu g g^{-1},\left(0.22 \mathrm{U} \mathrm{g}^{-1}\right) \\
\left.\chi^{2}=0.591, \mathrm{df}=2, \mathrm{p}=0.667\right)\end{array}$ \\
\hline
\end{tabular}

fore approximately $189 \mathrm{U} \mathrm{ml}^{-1}$ for 47666-1 CFSE and $192 \mathrm{U} \mathrm{ml}^{-1}$ for ACMM 642 CFSE (Table 5). Based on these values, a $1 \mathrm{ml}$ dose of CFSE in $150 \mathrm{ml}$ of seawater delivered a dose of $1.26 \mathrm{U} \mathrm{ml}^{-1}$ for $47666-1 \mathrm{CFSE}$ and $1.28 \mathrm{U} \mathrm{ml}^{-1}$ for ACMM $642 \mathrm{CFSE}$.

The virulence of strains ACMM 642 and $47666-1$ was shown clearly in this experiment. These strains caused $100 \%$ mortality of larvae from an inoculum of $10^{6} \mathrm{CFU}$ $\mathrm{ml}^{-1}$. As expected, an inoculum of $10^{4} \mathrm{CFU} \mathrm{\textrm {ml } ^ { - 1 }}$ resulted in approximately $100 \%$ mortality with strain 47666-1 and approximately $50 \%$ mortality with strain ACMM 642. Challenge of the larvae with CFSE of strains $47666-1$ and ACMM 642 or with their culture broths from $1 \mathrm{ml}$ down to $10 \mu \mathrm{l}$ resulted in survival which was significantly lower than that for untreated control flasks $(p<0.05)$. However, the effect of CFSE down to $10 \mu \mathrm{l}$ was not statistically different from the effect of bacterial culture broth $(p>0.05)$. Challenge with $1 \mu \mathrm{l}$ CFSE or culture broth (i.e. treatments 15,16 and 17 ) resulted in larval survival similar to that for untreated control flasks.

\section{PAGE analysis of CFSE}

Native-PAGE revealed protein bands in the CFSE from the toxic Vibrio harveyi strains ACMM 642 and 47666-1 which were distinctive and absent in the non-toxic strains studied (Fig. 2). These proteins were designated T1 (from strain 47666-1) and T2 (from strain ACMM 642) (Fig. 2). They appeared to be produced in large quantities, as indicated by the high intensity of staining in comparison to other extracellular proteins. Uninoculated luminous broth, spun through an Ultrafree 15 centrifugal filter, did not show any bands when electrophoresed on PAGE gels under the same conditions (not shown).

\section{PAGE analysis of proteins contained in toxic fractions}

When 47666-1 CFSE fractions from gel filtration were tested in bioassays (Table 3 ) and electrophoresed on native-PAGE gels, it was found that a single protein band occurred in toxic fractions 16,17 and 18 (CPF 16-18). An example gel is shown for the most toxic fraction CPF 17 in Fig. 3, lane 2, which can be compared to the CFSE from which it was derived in lane 1. Additional protein bands appeared when gels were silver stained and developed for a prolonged time (not shown). However, these additional bands were observed in the other, non-toxic fractions in greater concentrations. These data indicated that a significant

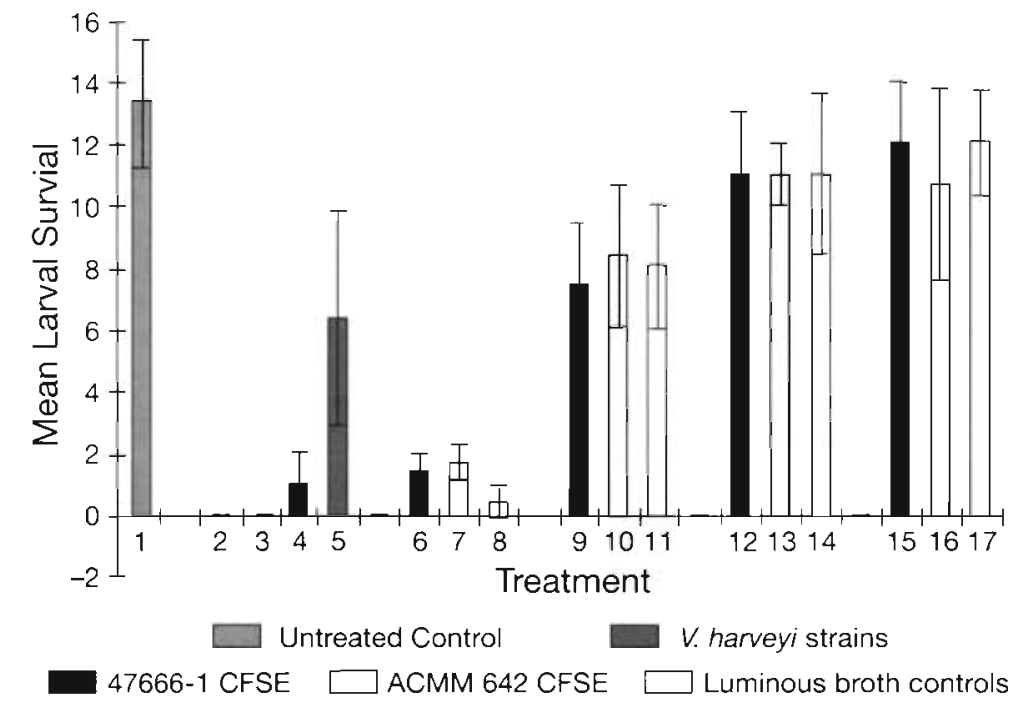

Fig. 1. Mean survival and standard deviation from 3 replicate flasks of Penaeus monodon protozoea $40 \mathrm{~h}$ after the following bath challenges. 1: untreated control; 2: Vibrio harveyi strain 47666-1 at $10^{6} \mathrm{CFU} \mathrm{m}^{-1} ; 3: \mathrm{V}$. harveyi strain 642 at $10^{6} \mathrm{CFU} \mathrm{ml^{-1 }}$; 4 : strain $47666-1$ at $10^{4} \mathrm{CFU} \mathrm{ml}^{-1}$; 5: strain 642 at $10^{4} \mathrm{CFU} \mathrm{ml}^{-1} ; 6,9,12,15$ : cell-free supernatant extract (CFSE) derived from 47666-1 at $1 \mathrm{ml}, 100 \mu \mathrm{l}, 10 \mu \mathrm{l}$, and $1 \mu \mathrm{l} ; 7,10,13,16$ : CFSE derived from ACMM 642 at $1 \mathrm{ml}, 100 \mu \mathrm{l}, 10 \mu \mathrm{l}$, and $1 \mu \mathrm{l} ; 8,11,14,17$ : luminous culture broth at $1 \mathrm{ml}, 100 \mu \mathrm{l}, 10 \mu \mathrm{l}$, and $1 \mu \mathrm{l}$ 


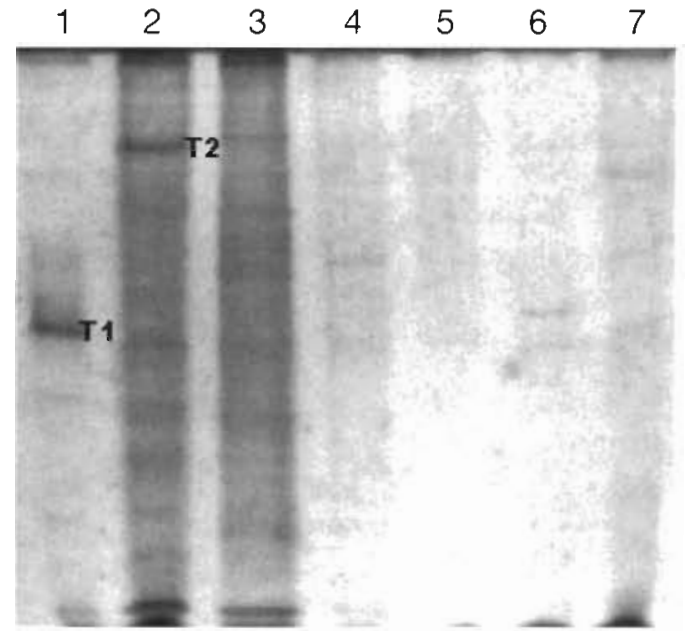

Fig. 2. Native-PAGE gel (10\%, Coomassie stained) of cell-free supernatant extract (CFSE) derived from broth cultures of toxic and non-toxic Vibrio harveys strains studied. T1: distinct protein expressed by toxic strain 47666-1; T2: distinct protein expressed by toxic strain ACMM 642; lane 1: toxic 47666-1 CFSE; lane 2: toxic $642 \mathrm{CFSE}_{\mathrm{i}}$ lane 3: non-toxic PM $91 \mathrm{CFSE}$ lane 4: non-toxic ACMM 656 CFSE; lane 5: non-toxic 46802-1 CFSE; lane 6: non-toxic M1 CFSE; lane 7: non-toxic ACMM 8 CFSE

purification of a proteinaceous exotoxin ( $\mathrm{T} 1$ ) had been achieved from strain 47666-1. From the intensity of staining of $\mathrm{T} 1$ in the original CFSE preparation (lane 1 , Fig. 3), it was apparent that this protein was a major extracellular protein produced at mid-exponential phase when the supernatant was harvested.

For strain ACMM 642 fractions from gel filtration, 2 proteins designated $T 2$ and $X$ (lane 4, Fig. 3) were detected in toxic fractions CPF2-4 under native-PAGE conditions by Coomassie staining. An example for $\mathrm{CPF}$ 3 is shown in Fig. 3, lane 4, next to the CFSE from which it was derived. This fraction was the most toxic fraction in the mice bioassay (Table 3 ). The larger protein, $X$, was expressed at greater concentration in fractions 2 and 1, which were less toxic than fraction 3 (Table 3 ). In addition, CPF 1, which contained only small amounts of T2 (not shown), was not toxic. As the peak intensity of protein $\mathrm{T} 2$ matched the toxicity of the fractions, it was considered to be the major proteinaceous toxin expressed by strain ACMM 642. As with strain 47666-1, prolonged development of a silver stain (not shown) revealed other proteins that were present in the first 4 fractions. Since these proteins were seen at greater concentration in non-toxic fractions (not shown), they were discounted as major toxins.

When the concentrated protein fractions containing $\mathrm{T} 1$ and $\mathrm{T} 2$ were electrophoresed under SDS-reducing conditions, the 47666-1 toxin T1 separated into 2 subunits of approximately 55 and $45 \mathrm{kDa}$ (Fig. 4), which gave the protein in native form a size of approximately

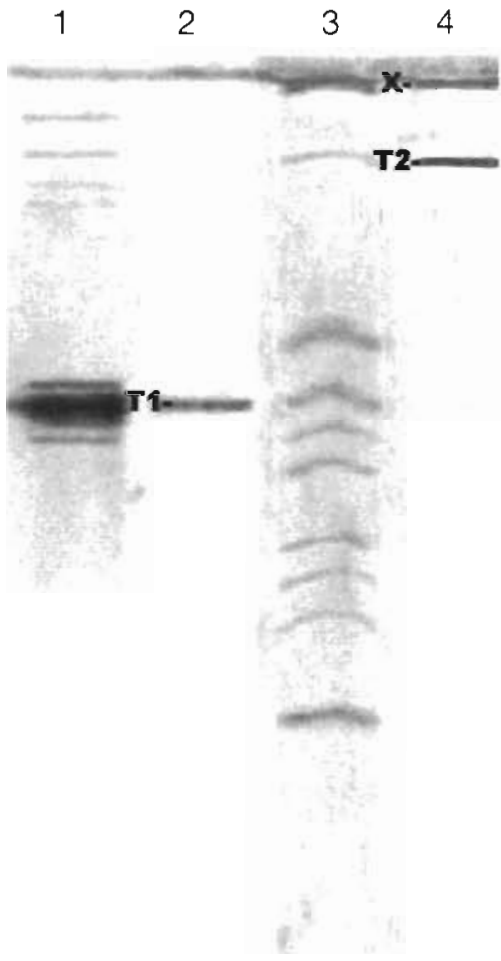

Fig. 3. Native-PAGE gel ( $10 \%$, Coomassie stained) of cell-free supernatant extract (CFSE) and concentrated protein fractions (CPF) derived from broth cultures of Vibrio harveyi strains 47666-1 and ACMM 642. T1: major toxic protein expressed by strain $47666-1$; T2: major toxic protein expressed by strain ACMM 642; X: major non-toxic protein expressed by strain ACMM 642; lane 1: CFSE of 47666-1; lane 2: CPF 17 of 47666-1; lane 3: CFSE of 642 ; lane 4 : CPF 3 of 642

$100 \mathrm{kDa}$. These subunits were very distinctive and corresponding bands could be seen in CFSE preparations.

CPF 3 from ACMM 642 containing T2 and X, separated into 7 major bands when electrophoresed under SDS-reducing conditions. Corresponding bands could also be seen in the CFSE and had molecular sizes of approximately $58,48,47,46,45,39$ and $21 \mathrm{kDa}$. Considering that the $\mathrm{T} 2$ band was the most intense protein band visible in this fraction under native-PAGE conditions, it may be that most of the bands on the SDS gel were derived from $\mathrm{T} 2$. If this were the case, $\mathrm{T} 2$ would be a larger protein than T1. However, since T2 and X were not separately purified, an approximate molecular size for $\mathrm{T} 2$ could not be estimated.

\section{Sequence analysis of toxins $\mathrm{T} 1$ and $\mathrm{T} 2$}

Protein sequencing was performed on proteins $\mathrm{T} 1$ and $\mathrm{T} 2$ in their native form in CPF 17 (T1) and CPF 3 (T2 and $\mathrm{X}$ ). Protein $\mathrm{T} 1$ was $\mathrm{N}$-terminal blocked so 


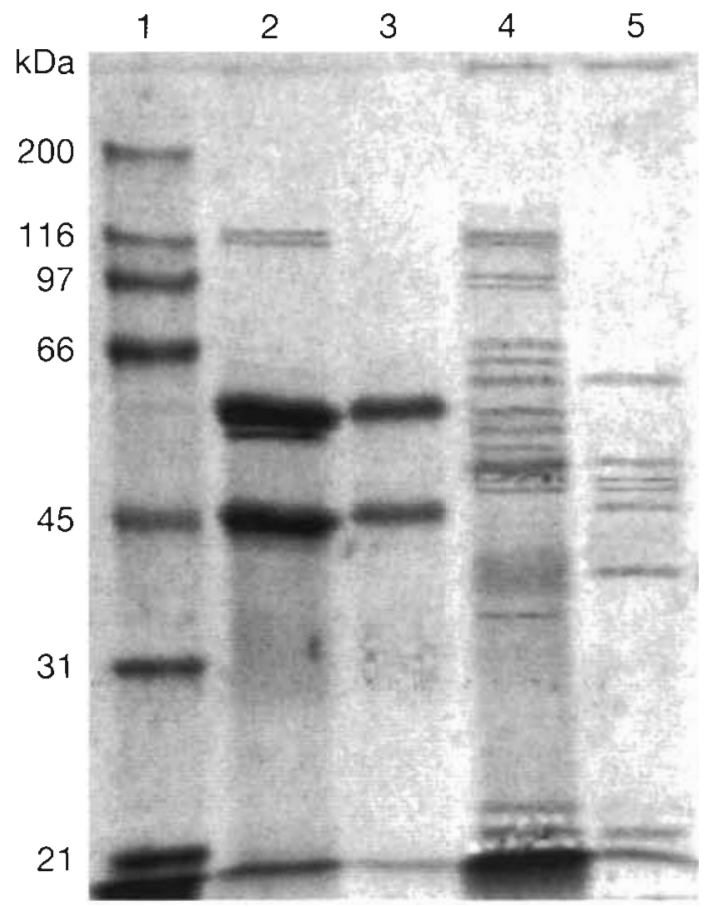

Fig. 4. SDS-PAGE gel (10\%, Coomassie-stained) showing cell-free supernatant extract (CFSE) and concentrated protein fraction (CPF) preparations for Vibrio harveyi strains 47666-1 and ACMM 642. Lane 1: broad range SDS-PAGE markers: lane 2: CFSE of 47666-1; lane 3: CPF 17, showing subunits of toxin $\mathrm{T} 1$; lane 4: CFSE of ACMM 642; lane 5: CPF 3, showing subunits resulting from reduction of toxin $\mathrm{T} 2$ and protein $\mathrm{X}$

internal sequencing was performed on the $\mathrm{N}$-terminal created by trypsin digestion. Two sequencing runs were performed on separate digests (Fig. 5).

Absolute purity was not required for protein sequencing, as the amino acid signals given by the sequencer resulted from the dominant protein present in the sample. T2 was the dominant protein in CPF 3. Thus, an N-terminal sequence was also obtained from protein T2 (Fig. 5).

The full $\mathrm{T} 1 \mathrm{~N}$-terminal sequence 1 returned no $100 \%$ homology match from the ANGIS database.

Protein T1 sequence 1:

$[$ Phe(F)Ser(S)]-Leu(L)-Ser(S)-Gly(G)-Asp(D)-Asn(N)-x-Glu(E)-Ile(I)

Protein $\mathrm{T} 1$ sequence 2:

$\operatorname{Asn}(N)-V a l(M)-P r o(P)-G l y(G)-G l u(E)-I l e(I)-V a l(V)-G l u(E)-x-L e u(L)$

Protein $\mathrm{T} 2 \mathrm{~N}$-terminal sequence:

$\operatorname{Ala}(A)-A s n(N)-T h r(T)-\operatorname{Val}(V)-A s n(N)-\operatorname{Val}(V)-A l a(A)-P h e(F)$

Fig. 5. Protein sequencing results for proteins $\mathrm{T} 1$ and $\mathrm{T} 2$. An unknown residue is indicated by $x$. Residues shown in brackets in sequence 1 for $T 1$ gave equally strong signals so the first residue was either Phe or Ser
Reducing the search to only the first 6 residues (FLSGDN) also returned no match with any known bacterial toxin or toxin-associated protein. However, the related sequence SLSGDN was $83 \%$ homologous with the sequence SLTGDN found in a family of virulenceassociated proteins from Salmonella and Shigella species. Attempted confirmation of this homology using a second internal sequence from protein $\mathrm{T} 1$ was unsuccessful. The complete 10 residue $\mathrm{N}$-terminal sequence 2 gave $100 \%$ homology with bovine beta-casein only. Reducing the number of residues in the search to NVPG resulted in a match to the internal sequence NVPG of the crystaline entomocidal toxin produced by Bacillus thuringiensis. Although the protein sequencing information returned no firm conclusions concerning the relatedness of toxin $\mathrm{T} 1$, some homology was found to toxin or toxin-associated proteins.

The N-terminal sequence of T2 did not return 100\% homology to any entry in the ANGIS database. When the inquiry was reduced to ANTV, 100\% homology was found for a sequence from inulin fructotransferase from Arthrobacter globiformis. This suggested T2 belonged to an uncharacterised group of proteins. The complete sequence matched poorly with internal sequences of a variety of proteins, none of which were toxins or toxin-associated.

\section{DISCUSSION}

In comparison with 8 avirulent strains, the extracellular proteins from 2 strains of Vibrio harveyi virulent to Penaeus monodon larvae produced mortality in CBA mice and juvenile $P$. monodon at low doses. The CFSE from 4 strains avirulent to larvae caused mortality of juvenile $P$. monodon at a dose of approximately $50 \mu \mathrm{g} \mathrm{g}^{-1}$. However, most bacterial exotoxins are lethal at doses less than this (Boyd 1984). Thus, the mortality seen from injection of CFSE from these avirulent strains was most likely due to the effects of lipopolysaccharide acting as an endotoxin.

Different protein toxins in the supernatant from broth cultures of 2 virulent strains were shown. The in vivo toxicity of these toxins was similar to toxins produced by related bacteria. For example, the $\mathrm{LD}_{50}$ of $2.1 \mu \mathrm{g} \mathrm{g}^{-1}$ for T1 and $3.1 \mu \mathrm{g} \mathrm{g}^{-1}$ for $\mathrm{T} 2$, by intra-peritoneal injection in CBA mice, was comparable to a Vibrio vulnificus cytolysin with an $\mathrm{LD}_{50}$ of $2.2 \mu \mathrm{g}$ $\mathrm{g}^{-1}$ in mice (Gray \& Kreger 1985). The $\mathrm{LD}_{50}$ of these toxins, by intra-muscular injection in Penaeus monodon, was $1.8 \mu \mathrm{g} \mathrm{g}^{-1}$ for $\mathrm{T} 1$ and $2.2 \mu \mathrm{g} \mathrm{g}^{-1}$ for T2. Another study re- 
ported an $\mathrm{LD}_{50}$ of $0.27 \mu \mathrm{g} \mathrm{g}^{-1}$ in Penaeus japonicus of a toxic protease produced by a $V$. alginolyticus strain (Lee et al. 1997). Although the $\mathrm{LD}_{50}$ s for the toxins produced by the 2 virulent strains examined here were similar, their sizes and structures were different. They were also produced in different quantities relative to other extracellular proteins. The $100 \mathrm{kDa} 11$ toxin, produced by the more virulent strain 47666-1, was the predominant protein produced by this strain in early to mid exponential phase of growth when the density of the culture was approximately $10^{9} \mathrm{CFU} \mathrm{ml} \mathrm{m}^{-1}$. This was probably the major reason for the extreme virulence of this strain. It can be assumed that this strain produced more toxin per bacterial cell than the less virulent strain ACMM 642, given the differences in density that were observed on Coomassie stained PAGE gels.

The major effect of toxins such as T1 and T2 probably occurs in the intestinal tract of infected Penaeus monodon larvae. In the rearing water of a commercial hatchery, levels of total culturable heterotrophic bacteria rarely rise above $10^{6} \mathrm{CFU} \mathrm{m}^{-1}$ (Maeda \& Nogami 1989) and it is only in situations of severe disease that Vibrio spp., as a proportion of the total heterotrophic population, approach levels greater than $10^{5} \mathrm{CFU} \mathrm{ml}^{-1}$ (Lavilla-Pitogo et al. 1990, Karunasagar et al. 1994). Unfortunately, the results of the larval toxicity assay performed in this study were equivocal. At the highest doses $(1 \mathrm{ml}$ and $100 \mu \mathrm{l})$ of CFSE, larvae were challenged with toxicity that was equivalent, in terms of $\mathrm{U} \mathrm{ml} \mathrm{m}^{-1}$, to $\mathrm{LD}_{50}(100 \mu \mathrm{l})$ or greater than $\mathrm{LD}_{50}(1 \mathrm{ml})$ doses that were injected $\mathrm{g}^{-1}$ in juvenile $P$. monodon or in mice. Significant mortality relative to the untreated control treatment was produced by challenge of the larvae with these doses. However, the mortality which resulted from challenging with an equivalent volume of luminous broth was similar.

The detrimental effect of broth from luminous cultures on the larvae did not assist interpretation of this experiment. This could have been due to 2 effects. Small protein digests present due to the peptone and yeast extract used in luminous broth could have been directly toxic to the larvae. However, it is more likely that the addition of extra nutrients present in luminous broth resulted in bacterial proliferation in these flasks. Protozoea were not sterilised prior to challenge so the addition of luminous broth could have stimulated the growth of pathogenic bacteria carried on the surface and in the intestines of the larvae, resulting in lower survival.

It is not likely that the major effects of toxins $\mathrm{T} 1 \mathrm{and}$ $\mathrm{T} 2$ arose from bacteria in the water column. It is far more likely that the toxins acted on gut epithelial cells, even if only to damage them and allow the bacteria a portal of entry to produce septicaemia. Counts of $10^{8}$ to

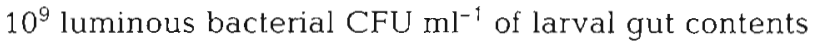

have been recorded from disease outbreaks of luminous vibriosis (Lavilla-Pitogo et al. 1990, Karunasagar et al. 1994). Our results indicate that such populations of toxin-producing Vibrio harveyi cells in the larval intestine would be very likely to cause the high larval mortality characteristic of luminous vibriosis outbreaks.

Partial sequencing of $\mathrm{T} 1$ and $\mathrm{T} 2$ did not identify these toxins. However, it was interesting for $\mathrm{T} 1$ that some homology match was found to toxins or virulence proteins produced by the bacterial gut pathogens, Salmonella typhimurium and Shigella flexneri. These toxins mediate transfer from the gut to other tissues in mouse madels (Sansonetti et al. 1986, Gulig \& Curtiss 1987). Transposon mutagenesis studies have shown that absence of these proteins reduces lethality (Sasakawa et al. 1986, Suzuki et al. 1994). Thus, it is possible that $\mathrm{T} 1$ enables luminous Vibrio species to passage the gut cells of Penaeus monodon and cause damage in other larval tissues. There may also be some similarity between the toxigenic sites of the protein T1 and the entomocidal toxin produced by Bacillus thuringiensis. Although this bacterium is not closely related to $V$. harveyi, there are some similarities in that $B$. thuringiensis is also a primary pathogen of invertebrates. $B$. thuringiensis causes disease through the action of its toxin on the mid-gut microvilli of lepidopteran larvae (Hofte \& Whiteley 1989). It is possible that toxin T1 also interacts with this region of the larval prawn gut.

Toxin T2 seems to be a relatively unique protein given the lack of homology of the complete $\mathrm{N}$-terminal sequence obtained with other entries in the ANGIS database. However, homology of the N-terminal ANTV sequence with that of a fructotransferase from Arthrobacter globiformis may indicate some functional similarity to other bacterial toxins. The sugar side-chain of gangliosides in the lipid bilayer of eucaryotic cells does bind to some bacterial toxins, enabling them to exert their effects. For example, cholera toxin binds to the galactose side-chain of ganglioside GM1 (Sears \& Kaper 1996) and botulinum toxin also binds to gangliosides (Sears \& Kaper 1996). This binding mimics the action of sugar transferases, which also bind to gangliosides to transport sugars into eucaryotic cells. Homology between T2 and a fructotransferase may indicate that binding with a gangliosidal fructose residue is required for its action. The large number of subunits seen in PAGE gels and thought to be derived primarily from $\mathrm{T} 2$ suggested that $\mathrm{T} 2$ might be a protoxin and that eucaryotic cell recognition and cleavage might be essential for its action.

A great deal of work remains to be done with these toxins. The purification methods used in this study resulted in concentrated protein fractions possessing approximately twice the specific activity $\mathrm{mg}^{-1}$ of CFSE. 
Purification by affinity chromatography methods would allow greater quantities to be isolated more easily, so that further characterisation of the toxins and their respective subunits could be performed.

Strains of pathogenic Vibrio harveyi in the Phillipines, Thailand, Indonesia and India with similar virulence to Penaeus monodon larvae may produce the same or similar exotoxins to those described here. Our discovery of 2 markedly different exotoxins in $2 \mathrm{~V}$. harveyi strains with different levels of virulence would be consistent with the suggestion of Pizzutto \& Hirst (1995) that the strain specific virulence of $V$. harveyi may be acquired through genetically mobile elements such as plasmids or bacteriophage carrying transposons or insertion sequences. Previous studies with strain 47666-1 showed that, although this strain carried a plasmid, its measurable activity was confined to transfer of antibiotic resistance factors (Harris 1993). Avirulent strains of $V$. harveyi that received this plasmid through conjugation acquired antibiotic resistance but not virulence to $P$. monodon protozoea (Harris 1993). However, transmission of virulence factors through infection by a bacteriophage may still be a possible means by which $V$. harveyi could acquire virulence genes. Characterisation of the genes which produce toxins $\mathrm{T} 1$ and $\mathrm{T} 2$ may reveal their source and facilitate a greater understanding of strain specific virulence in $V$. harveyi.

Acknowledgements. This study was funded by the Cooperative Research Centre for Aquaculture as was the personal scholarship of L.J.H. The assistance provided by Jane Oakey of the Dept of Microbiology and Immunology, James Cook University, in the writing of this manuscript is also gratefully acknowledged.

\section{LITERATURE CITED}

Boyd R (1984) Host-parasite interactions. In: Bowen L (ed) General microbiology. Times Mirror/Mosby Publishing, St. Louis, MO, p 513-516

Brown C, Roland G (1984) Characterisation of exotoxin produced by a shellfish-pathogenic Vibrio sp. J Fish Dis 7 $117-126$

DiSalvo LH, Blecka J, Zebal R (1978) Vibrio anguillarum and larval mortality in a California coastal shellfish hatchery Appl Environ Microbiol 35(1):219-221

Fukasawa S, Nakamura K, Miyahira M, Kurata M (1988) Some properties of two proteinases from a luminous bacterium, Vibrio harveyi strain FLN-108. Biol Chem 52(12) 3009-3014

Fukasawa S, Miyahira M, Hosoda M, Kurata M (1989) Properties of the proteinase from a luminous bacterium, Vibrio harveyi strain FLN-77. Chem Pharm Bull (Tokyo) 37(1): 204-205

Gray LD, Kreger AS (1985) Purification and characterisation of an extracellular cytolysin produced by Vibrio vulnificus. Infect Immun 48(1):62-72

Gulig PA, Curtiss R (1987) Plasmid-associated virulence of Salmonella typhimurium. Infect Immun 55:2891-2901
Harris LJ (1993) An investigation into the virulence of strains of Vibrio harveyi pathogenic to larvae of the tiger prawn Penaeus monodon. Honours thesis, James Cook University of North Queensland, Townsville

Hofte H, Whiteley HR (1989) Insecticidal crystal proteins of Bacillus thuringiensis. Microbiol Rev 53(2):242-255

Honda T, Ni Y, Miwatani T, Adachi T, Kim J (1992) The thermostable direct haemolysin of Vibrio parahaemolyticus is a pore forming toxin. Can J Microbiol 38:1175-1180

Jiravanichpaisal P, Miyazaki T, Limsuwan C (1994) Histopathology, biochemistry and pathogenicity of Vibrio harveyi infecting black tiger prawn Penaeus monodon. $\mathrm{J}$ Aquat Anim Health 6:27-35

Karunasagar l, Pai R, Malathi GR, Karunasagar I (1994) Mass mortality of Penaeus monodon larvae due to antibioticresistant Vibrio harveyi infection. Aquaculture 128:203-209

Laemmli UK (1970) Cleavage of structural proteins during the assembly of the head of bacteriophage T4. Nature 227 : $680-685$

Lavilla-Pitogo CR, Baticados MCL, Cruz-Lacierda ER, de la Pena LD (1990) Occurrence of luminous bacterial disease of Penaeus monodon larvae in the Philippines. Aquaculture 91:1-13

Lee KK, Yu SR, Liu PC (1997) Alkaline serine protease is an exotoxin of Vibrio alginalyticus in kuruma prawn, Penaeus japonicus. Curr Microbiol 34:110-117

Liu PC, Lee KK, Chen SN (1996a) Pathogenicity of different isolates of Vibrio harveyi in tiger prawn, Penaeus monodon. Lett Appl Microbiol 22:413-416

Liu PC, Lee KK, Tu CC, Chen SN (1996b) Purification and characterisation of a cysteine protease produced by pathogenic luminous Vibrio harveyi. Curr Microbiol 35:32-39

Maeda M, Nogami K (1989) Some aspects of the biocontrolling methods in aquaculture. In: Miyashi S, Karube I, Ishida $Y$ (eds) Current topics in marine biotechnology. Japanese Society for Marine Biotechnology, Tokyo, p 395-398

Muir PR (1991) Factors affecting the survival of penaeid prawns. PhD thesis, James Cook University of North Queensland, Townsville

Owens L, Austin DA, Austin B (1996) Effect of strain origin on siderophore production in Vibrio harveyi isolates. Dis Aquat Org 27:157-160

Pizzutto M. Hirst RG (1995) Classification of isolates of Vibrio harveyi virulent to Penaeus monodon larvae by protein profile analysis and M13 DNA fingerprinting. Dis Aquat Org 21:61-68

Reichelt JL, Baumann P (1973) Taxonomy of the marine luminous bacteria. Arch Microbiol 94:283-330

Ruangpan L, Danayadol Y, Direkbusarakom S, Sriurairatana S, Flegel TW (1999) Bacteriophage implicated in mortality of cultivated Penaeus monodon exhibiting tea-brown gill syndrome (TBGS). Dis Aquat Org 135:195-201

Sansonetti PJ, Ryter A, Clerc P, Maurelli AT, Mounier J (1986) Multiplication of Shigella flexneri within HeLa cells: lysis of the phagocytic vacuole and plasmid-mediated contact hemolysis. Infect Immun 51:461-469

Sasakawa C, Makino S, Kamata K, Yoshikawa M (1986) Isolation, characterisation, and mapping of Tn5 insertions into the 140-megadalton invasion plasmid defective in the mouse Sereny test in Shigella flexneri 2a. J Bacteriol 170: $2480-2484$

Sears CL, Kaper JB (1996) Enteric bacterial toxins: mechanisms of action and linkage to intestinal secretion. Microbiol Rev 60(1): $167-215$

Simidu U, Noguchi T, Hwang DF, Shida Y, Hashimoto $K$ (1987) Marine bacteria which produce tetrodotoxin. Appl Environ Microbiol 53(7):1714-1715 
Sunaryanto A, Mariam A (1986) Occurrence of a pathogenic bacteria causing luminescence in penaeid larvae in Indonesian hatcheries. Bull Brackishwater Aquacult Dev Cent 8:64-70

Suzuki S, Komase K, Matsui $H$, Abe A, Kawahara K, Tamura Y, Kijima M, Danbara H, Makamura M. Sato S (1994) Virulence region of plasmid pNL2001 of Salmonella enteritidis. Microbiology 140:1307-1318

Svitil AL, Chadhain SM, Moore JA, Kirchman DL (1997)

Editorial responsibility: Timothy Flegel,

Bangkok, Thailand
Chitin degradation proteins produced by the marine bacterium Vibrio harveyi growing on different forms of chitin. Appl Environ Microbiol 63(2):408-413

Venkateswaran $K$, Horiuchi $H$, Nakano $H$, Matsuda $H$, Hashimoto $H$ (1991) Vibrio virulence factors and the quantitative analysis of cytotoxicity elaborated by environmental isolates. Cytobios 66:143-151

Yasumoto T, Murata M (1993) Marine toxins. Chem Rev 93(5): $1897-1909$

Submitted: April 6, 1998; Accepted: May 3, 1999

Proofs received from author(s): September 6, 1999 